\title{
ABOUT THE FINANCIAL REPORTING ON THE CAPITAL MARKETS IN THE EUROPEAN UNION: REQUIREMENTS OF USING THE IFRS AND THE EQUIVALENCE OF THIRD COUNTRY ACCOUNTING STANDARDS
}

\author{
Aristița Rotilă \\ "Vasile Alecsandri” University of Bacău \\ rotila11@yahoo.com
}

\begin{abstract}
The need to build a single European market and to ensure the competitiveness of the community capital markets led to the involvement of European Union in the convergence process taking place on a global level in the realm of financial reporting. This paper is a study on financial reporting for the capital markets in the European Union by analyzing the accounting standards that need to be applied. Specifically, this paper highlights a number of issues concerning: the adoption of IAS / IFRS in the European Union and their compulsory aspect in preparing the consolidated financial statements for the companies listed on $a$ regulated market; the requirement's extension of using the IFRSs adopted in the European Union to the issuers of certain third countries involving a public offer of securities in European Union or performing transactions with securities on a community regulated market; the establish of a mechanism for the determination of equivalence of certain third country accounting standards with IFRSs in force at European level and, consequently, the possibility of using by some third country issuers, in preparing the consolidated financial statements submitted to the European markets, recognized national standards as equivalent to adopted IFRS.
\end{abstract}

\section{Keywords}

accounting; standards; convergence; equivalence; IFRS; European Union; third country

\section{JEL Classification}

M41

\section{Introduction}

In order to accelerate the creation of an integrated assets market meant to work in a real, equilibrated and efficient manner in the European Union immediate measures needed to be taken in the field of financial communication. The European Commission adopted the IAS/IFRS standards and it imposes their application for elaboration of the consolidated financial statements of the European societies that are marketable on a regulated market. Later, the request regarding the use of the IAS/IFRS standards adopted in the European Union also comprised the issuers from third countries who come with a public offer of securities in the Union or who transact securities on a communitarian-regulated market. Moreover, at a European level, a mechanism for the determination of the equivalence of accounting national standards from third countries to the IAS/IFRS standards adopted in the European Union was established. Therefore, the securities issuers from third countries are allowed to apply the national accounting standards of certain third countries that are recognized as being equivalent to the adopted IFRS when elaborating consolidated financial statements presented on the European markets. 


\section{About Adopting the IAS/IFRS Standards in the EU and the Obligatory Character of their Use}

Because the requests regarding the financial reporting established by the European directives concerning the accounting were not able to ensure the high transparency and comparability level of the financial reports requested both by investors and by the surveillance authorities for all the marketable communitarian societies, the completion of the legal framework applicable for the marketable societies became necessary for the elaboration of their consolidated financial statements. At the same time, it was important for the financial reporting norms applied by the communitarian societies from the financial markets to be accepted internationally and to represent real global standards. This involves a high convergence of the accounting standards, the final target being the making of a unique set of accounting standards used at a global level and based on principles, standards that are meant to ensure the making of a coherent and homogenous financial reporting. In some specialists' opinion (Granier, 2003, page 2), these worldwide-recognized standards should facilitate at the same time the international transactions and the unification of the capital markets.

Hence, aiming to harmonize the financial information presented by societies whose titles are admitted for transactions on the regulated market of a member state and in order to ensure a high transparency and comparability level of the financial statements and, therefore, an efficient and competitive functioning of the communitarian capital markets and the making of a unique market, the European Union decided to adopt and use International Accounting Standards. For this reason, the Regulation (EC) no. 1606/2002 of the European Parliament and of the Council of 19 July 2002 on the application of the International Accounting Standards (also called the "IAS Regulation") was adopted. Based on the IAS Regulation, when elaboration the consolidated financial statements the societies that are regulated by the internal law of a state that is a member of the European Union and whose securities are admitted for transactions on a regulated market of any member state must apply the IAS/IFRS standards adopted by the European Union for each financial year that starts on January $1^{\text {st }} 2005$ or after this date.

At the same time, the IAS Regulation (Art. 5) empowers the member states to impose or authorize the application of this framework in case of the consolidated financial statements of the societies whose titles are not admitted for transaction on the regulated market of a member state as well as in case of the individual financial statements, no matter whether the society is admitted or not for transaction on a regulated market of the European Union.

After adopting the IAS Regulation, different countries introduced the IAS/IFRS standards directly in the national accounting regulations. This obviously proves that one of the objectives of this regulation, namely that of encouraging the convergence of the accounting standards so that the IAS/IFRS standards are internationally accepted and become real global standards is in the process of accomplishment. At the same time, in order for the European accounting directives not to represent a barrier in the way of application of the international standards starting with 2005, they were subject to modernization.

The IAS/IFRS adoption in the European Union is made according to procedure that was established by the IAS Regulation, by following a process in stages finished with the elaboration of a Regulation (EC) by the European Commission and its publishing (including the adopted standard) in the Official Journal of the European Union. The IAS/IFRS adoption in the European Union implies the approval by means of a mechanism endowed with a double structure (with two levels): a political (regular) level, assured by an Accounting Regulatory Committee - ARC; a technical level, the European Financial Reporting Advisory Group - EFRAG, with a Technical Expert Group - TEG and a Supervisory Board. EFRAG must provide the assistance and 
competence requested for the evaluation of the IAS/IFRS norms and for the guidance of the Commission as regards the opportunity to modify or not the European law in force. Moreover, in order to guide the Commission as regards the objectivity and neutrality of the EFRAG notices regarding the adoption of the IFRS standards and of the IFRIC interpretations, in July 2006 (by Decision 2006/505/CE of the Commission, published in the Official Journal of the EU, L199/2006) a group of accounting experts called the Standards Advice Review Group - SARG was established.

In July 2003, the Accounting Regulatory Committee advised the European Commission to adopt all the IAS and Interpretations (SIC) in existence on 14 September 2002, except those referring to the financial instruments (IAS 32 Financial Instruments: Disclosure and Presentation, IAS 39 Financial Instruments: Recognition and Measurement and their interpretation: SIC 5, SIC 16 and SIC 17) because they are in process of major revision as part of the Improvement Project of the International Accounting Standards Board (IASB). Taking into account this recommendation, the European Commission adopted all the existing Standards and Interpretations, seen the mentioned exceptions, by Regulation (EC) no. 1725/2003 (published in the Official Journal of the EU L 261/2003).

Subsequently, by Regulation (EC) no. 2086/2004 and 2237/2004, the reviewed versions (2003) of the IAS 32 and IAS 39 standards (with two exceptions: the provisions on the use of the fair value option and certain provisions relating to hedge accounting) were also adopted. Also, the new International Financing Reports Standards (from IFRS 1 to IFRS 13, except IFRS 9) and Interpretations (from IFRIC 1 to IFRIC 20, except IFRIC 3, which was revoked before becoming effective) issued by IASB after 14 September 2002, as well as the reviewed variants or some amendments or improvements brought to the already existing standards were adopted. As regards the IFRS 9, both the date for the EFRAG notification and the approval date by ARC were postponed (see EFRAG, 2013).

We must say that the Regulation (EC) no. 1725/2003 regarding the adoption of the international accounting standards (including subsequent amendments and completions) was replaced by the Regulation (CE) no. 1126/2008, which includes the consolidated text of all the IAS/IFRS standards, as well as the SIC/IFRIC interpretations that were adopted at a communitarian level until 15 October 2008, except the IAS 39 standard, of which certain parts were omitted (namely certain provisions relating to hedge accounting). Therefore, all the regulations issued after this date for the adoption of new standards appear as regulations "amending Regulation (EC) no. 1126/2008 [...]”.

In some authors' opinion (Gîrbină \& Bunea, 2007), the adoption of the international referential by the European Union "is a result of a strategic option which answers the convergence objective”.

\section{Extended Requests regarding the Use of the IFRS Adopted in the EU}

The obligation regarding the use of the IAS/IFRS adopted by the European Union in the elaboration of the financial reports was later extended over the issuers of third countries as well, by means of two regulations, namely:

- By means of the Regulation regarding the prospectus (Regulation (EC) no. 809/2004), for the appliance in case of the third countries issuers who make a public offer of securities in the EU as well; this regulation brings into force the Directive 2003/71/EC of the European Parliament and of the Council (called "the Directive regarding the prospectus”); 
- By means of the Directive regarding transparency (Directive no. 2004/109/EC of the European Parliament and of the Council), for the appliance in case of the third countries issuers whose titles are transacted on a regulated market from the EU.

These regulations stipulate that the issuers from third countries must present the financial information /financial statements elaborated according to the IFRS adopted pursuant to Regulation (EC) no. 1606/2002 or according to the national accounting standards from a third country (the GAAPs of the third country) that are the equivalent of these standards. The information /financial statements that are not elaborated according to the adopted IFRS or the GAAPs from a third country that are the equivalent of these standards must be presented as reformulated financial information /financial statements.

We must say that through its recommendation of June 2005 the Committee of European Securities Regulators (CESR) considered that, on the whole, the GAAPs of the United States, Canada and Japan are equivalent to IFRS adopted in the EU pursuant to Regulation (EC) no. 1606/2002, subject to certain conditions like providing extra information and, in certain cases, supplementary financial statements. In this recommendation, CESR explains that equivalent does not mean identical and it considers that certain differences between the GAAPs of third countries and the IAS/IFRS would not lead to the making of different decisions regarding the investments.

The possibility to use the national accounting standards from a third country without having to reformulate the financial information /financial statements initially was the object of a transitory exemption until 1 January 2007. Then, considering the efforts of the national authorities of accounting normalization in Canada, Japan and the United States of America, as well as the efforts of other jurisdictions and taking into account the continuous efforts regarding the convergence to the IFRS, it was agreed to postpone this date for another two years. For this aim, in December 2006, the Commission adopted two judicial measures regarding the use of the information elaborated according to certain internationally accepted accounting standards by the issuers from third countries, namely Regulation (EC) no. 1787/2006/EC amending the Regulation (EC) no. 809/2004; the Commission Decision no. 2006/891/EC regarding the use of the information elaborated according to the internationally accepted accounting standards called "Decision according to the Directive regarding transparency") by securities' issuers from third countries.

According to these dispositions (Decision 2006/891/EC, Art.1, and the Regulation (EC) no. 809/2004, Art. 35, paragraph (5A), as amended by the Regulation (EC) no. $1787 / 2006 / E C)$, the issuers residing in a third country can use the GAAPs of a third country in the elaboration of the historic financial information included in a prospectus submitted to a competent authority before 1 January 2009 (according to the Regulation regarding the prospectus), respectively in the elaboration of annual and semestrial consolidated financial statements for all the financial years that start before January 2009 (according to the Directive regarding transparency), without having to reformulate them or to provide a description of the differences between the IFRS adopted pursuant to Regulation (EC) no. 1606/2002 and the GAAPs according to which these financial information /financial statements were elaborated when one of the following conditions is accomplished:

- The notes that are attached to the financial statements contain an explicit and unreserved statement regarding the conformity of the financial information /financial statements with IFRS, according to IAS 1 Presentation of Financial Statements;

- The financial information /financial statements are elaborated according to the GAAPs of either Canada, Japan or the United States of America; 
ABOUT THE FINANCIAL REPORTING ON THE CAPITAL MARKETS IN THE EUROPEAN UNION: REQUIREMENTS OF USING THE IFRS AND THE EQUIVALENCE OF THIRD COUNTRY ACCOUNTING STANDARDS

- The financial information /financial statements are elaborated according to the GAAPs of a third country, other than Canada, Japan or the United States of America and the following conditions are accomplished:

1) The given authority of the third country which is responsible with the national accounting standards has publicly engaged itself to realize the convergence of these standards to the IFRS before the beginning of the financial year (during which the prospectus was submitted or for which the financial statements is reported);

2) The said authority has established a work programme which demonstrates the intention to progress towards convergence before 31 December 2008; and

3) The issuer proves that the conditions mentioned at points 1) and 2) are accomplished.

During this 2 year period, the Commission's main task is to keep an active dialogue with the authorities in question from the third countries, to carefully supervise the evolution of the convergence between the IFRS and the GAAPs of Canada, Japan, the United States and other countries that have established a convergence program (in order to be sure that it is able to make a decision about the equivalence at least six months before 1 January 2009) and, even more, to actively monitor the evolution of the authorities in question from the third countries in order to eliminate the reconcilement obligations imposed to the EU issuers who enter the financial markets from a third country. At the same time, during this period, the Commission must regularly inform the Committee of European Securities Regulators and the European Parliament about the progresses regarding the convergence between the IFRS and the national accounting standards of the previously mentioned third countries about the progresses regarding the elimination of the reconcilement obligations imposed to the EU issuers in these third countries.

\section{The Definition of Equivalence and the Institution of the Equivalence Mechanism of the Accounting Standards}

In order to establish if the GAAPs of a third country are equivalent to IFRS adopted in the EU, was necessary, first, to elaborate a definition of the equivalence and establish a mechanism for the determination of equivalence. According to the European legislation (namely the Regulation regarding the prospectus and the Decision in conformity with the directive regarding transparency) such obligations fell on the European Commission that also had the obligation to establish the equivalence of the third countries GAAPs, according to a certain calendar (at least 6 months before 1 January 2009). As regards each of the above mentioned aspects, the Commission must refer to the Committee of European Securities Regulators (CESR). Following the first consultation, CESR proposed the following definition of equivalence that, in the Commission's opinion, provides adequate criteria for the defining equivalence "For equivalence's purposes, investors should be able to make a similar decision irrespective of whether they are provided with financial statements based on IFRS or on third country GAAP" (see Commission of the European Communities, 2007).

Given the objectives of "the Directive regarding the prospectus" (Directive no. 2003/71/CE), of assuring that the investors are able to make a documented evaluation of an issuer's assets and debts, financial position, results and prospectus and the objectives of "the Directive regarding transparency" (Directive no. 2004/109/EC), of allowing the investors to make a documented evaluation of the financial statement of the issuers' whose securities are admitted to be transacted on a regulated market, the 
equivalence had to be defined by reference to the investors' ability to make a similar evaluation of the financial position and of the prospectus, no matter whether the financial statements are elaborated according to the accounting standards of a third country or according to the IFRS. Hereupon, in 2007, the European Commission published a Regulation by which it establishes the conditions according to which the GAAPs of a third country may be considered to be equivalent to IFRS and a mechanism for the determination of equivalence is constituted. This is about the Commission Regulation (EC) no. 1569/2007 establishing a mechanism for the determination of equivalence of accounting standards applied by third country issuers of securities, pursuant to Directives 2003/71/EC and 2004/109/EC of the European Parliament and of the Council (published in the Official Journal of the EU no. L 340/2007).

By virtue of this Regulation (Art.2) the generally accepted accounting principles of a third country may be considered equivalent to IFRS adopted pursuant to Regulation (EC) no. 1606/2002 "if the financial statements drawn up in accordance with Generally Accepted Accounting Principles of the third country concerned enable investors to make a similar assessment of the assets and liabilities, financial position, profit and losses and prospects of the issuer as financial statements drawn up in accordance with IFRS, with the result that investors are likely to make the same decisions about the acquisition, retention or disposal of securities of an issuer".

The decision on the evaluation of third country GAAPs equivalence can be made by the Commission: upon request of the competent authority of a member state, upon request of an authority that is responsible for the accounting standards or for the supervision of the market from a third country or on its own initiative.

The Regulation stipulates specific and transitory dispositions for third countries that before 30 June 2008 - publicly committed themselves to accomplish the convergence of the national accounting referential to the IFRS until 31 December 2011 or, together with the European Union, came to an agreement of mutual acknowledgement before 31 December 2008. In other words, a new extension of the derogation granted to the securities issuers from the third countries regarding the use of the IFRS (between 1 January 2009 and 31 December 2011) is made.

The issues regarding convergence are the object of the discussions representing the dialogue between the regulation authorities and, for this purpose, the Commission and the authorities of the third countries in question are in regular contact. The Commission must regularly inform the Committee of European Securities Regulators and the European Parliament on the evolution of the discussions between the regulatory authorities and on the progresses in the way of convergence to the IFRS of the third countries.

\section{The National Accounting Standards Recognized as Equivalent to IFRS Adopted by the EU}

The efforts regarding the convergence and the progresses registered in some countries determined the Committee of European Securities Regulators (later, from 1 January 2011, replaced by the European Securities and Market Authority - ESMA), respectively the European Commission to consider that it is advisable for the GAAPs of certain third countries to be regarded as equivalent to IFRS adopted by the EU. Therefore, the securities issuers from third countries are allowed to apply the national accounting standards of certain third countries that are recognized as being equivalent to the adopted IFRS when elaborating consolidated financial statements presented on the European markets.

As we already showed, even from 2005, the Committee of European Securities Regulators considered that, each taken as a whole, the GAAPs from the United States, 
ABOUT THE FINANCIAL REPORTING ON THE CAPITAL MARKETS IN THE EUROPEAN UNION: REQUIREMENTS OF USING THE IFRS AND THE EQUIVALENCE OF THIRD COUNTRY ACCOUNTING STANDARDS

Canada and Japan are equivalent to IFRS adopted by the EU (subject to certain conditions) and they were temporarily admitted in order to be used in the elaboration of the information for the reporting on the regulated markets from the EU.

After the constitution of the equivalence mechanism, in its advice on the equivalence of the accounting standards from the United States of America, Japan and China and then Canada and South Korea, then India (issued in March, CESR/08-179, in May, CESR/08-293, and in November 2008, CESR/08-859) to the IFRS, the Committee of European Securities Regulators advised the European Commission to recognize the GAAPs from the United States of America and the GAAPs from Japan as being the equivalents of the IFRS in force at an European level and to temporary accept, at a communitarian level, the financial statements elaborated based on the GAAPs from China, Canada, South Korea and India, until no longer than 31 December 2011.

Therefore, in December 2008, the Commission adopted the Regulation (EC) no. 1289/2008 regarding the amendment of the Regulation (EC) no. 809/2004 and the Decision no. 2008/961/EC, which establishes that starting with 1 January 2009 the issuers from third countries present the financial information elaborated according to any of the following accounting standards:

- The IFRS adopted by the EU pursuant to Regulation (EC) no. 1606/2002;

- The IFRS, provided that the notes to the audited financial statements that form part of the historic financial information contain an explicit and unreserved statement that these financial statements comply with the IFRS according to the

IAS 1 Presentation of Financial Statements;

- The GAAPs from the United States of America;

- The GAAPs from Japan.

At the same time, by Regulation (EC) no. 1289/2008 and by Decision no. 2008/961/EC the Commission authorizes the issuers of the third countries to elaborate their financial statements according to the GAAPs from China, Canada, South Korea and India, before the financial years that start with 1 January 2012 or after this date, without having to reformulate the historic financial information comprised in a prospectus (stipulated by the Regulation (EC) no. 809/2004, Annex I point 20.1; Annex IV point 13.1; Annex VII point 8.2; Annex X point 20.1 or Annex XI point 11.1) or the obligation (stipulated by the Regulation (EC) no. 809/2004, Annex VII point 8.2a; Annex IX point 11.1; or Annex X point 20) to provide a narrative description of the differences between the IFRS adopted by the EU and the GAAPs according to which such information is elaborated.

In February 2009 and in June 2010, the Commission asked the Committee of European Securities Regulators to provide a technical evaluation of the registered progresses for the convergence of their accounting standards or for the adoption of the IFRS in the countries where EU granted a transition period when passing to the IFRS (China, Canada, South Korea and India) and the reports were presented by the CESR in June 2009 (Report CESR/09-472), respectively in November 2010 (Report CESR/10-1301).

Although the validity period regarding the conditions in which the equivalence for the GAAPs from China, Canada, South Korea and India was to be granted was going to expire on 31 December 2011, the Commission evaluated the utility and functioning of the equivalence mechanism and it concluded that this should be extended for a 3 year period, respectively until 31 December 2014. For this reason the Commission Delegated Regulation (EU) no. 310/2012 (which amended the Regulation (EC) no. 1596/2007) was adopted. Also, the Commission Implementing Decision no. 2012/194/EU (which amended the Decision no. 2008/961/EC) was issued, establishing that from 1 January 2012 the GAAPs from China, Canada and South Korea are considered to be equivalent to IFRS adopted by the EU pursuant to 
Regulation (EC) no. 1602/2002 and the transition period is extended by three years, until 31 December 2014, to grant the issuers from third countries the possibility to elaborate their consolidated financial statements according to the GAAPs from India. In the making of this decision, the Commission considered the technical evaluation presented by the CESR in its Report from November 2010 regarding the said countries and the updated information referring to China and India received from ESMA in May 2011. As about India, we need to mention that after an investigation made on the scene in January 2011, ESMA observed that the accounting standards present several differences in comparison with the IFRS and, therefore, there are uncertainties regarding the calendar of application of a reporting system according to the IFRS.

Apart from the third countries whose GAAPs are considered to be equivalent to IFRS adopted in the EU, there are several countries like Australia, Hong Kong, New Zealand, Singapore, South Africa, who have already fully adopted or implemented the IFRS. In their case, is no need for a decision on equivalence by the European Commission. Also, there are several developed economies that want to adopt the IFRS (which have undertaken to converge their accounting standards to IFRS or to adopt them). In their case the European Commission, assisted by the ESMA, will continue to monitor the situation, to evaluate and support their efforts.

\section{Conclusions}

The approached aspects represent actions carried on at a European level and that, together with the European directives' modernization, prove that the European Union is firmly engaged on the line of a global financing reporting system and it is strongly involved in the global convergence process of financial reporting. The European Commission welcomes all the initiatives that create the necessary conditions for the IFRS to become global standards. The efforts and the registered progresses as regards the convergence to the IFRS from certain third countries determined the European Authority for Securities and Markets and the European Commission to consider that their accounting standards are equivalent to IFRS adopted in the EU and, therefore, to allow their use in the elaboration of the consolidated financial statements for financial reporting on the capital markets from the EU member states. Therefore, for the financial reporting on a regulated market of the EU, the European societies use the IFRS adopted in the EU when it comes of the elaboration of their consolidated financial statements, while the societies from the third countries can use either the IFRS adopted in the EU, or the IFRS adopted by the IASB, or the accounting standards of third countries that are considered to be equivalent to IFRS adopted in the EU.

\section{References}

Commission of the European Communities (2007), First report to the European Securities Committee and to the European Parliament on convergence between International Financial Reporting Standards (IFRS) and third country national Generally Accepted Accounting Principles (GAAPs), [COM(2007) 405 final], Brussels, 6.7.2007, available on http://ec.europa.eu/internal_market/ accounting/docs/com-2007-0405_en.pdf.

Committee of European Securities Regulators (2008), CESR's advice on the equivalence of Chinese, Japanese and US GAAPs (CESR/08-179), March 2008, www.esma.europa.eu. 
ABOUT THE FINANCIAL REPORTING ON THE CAPITAL MARKETS IN THE EUROPEAN UNION:

REQUIREMENTS OF USING THE IFRS AND THE EQUIVALENCE OF THIRD COUNTRY ACCOUNTING STANDARDS

Committee of European Securities Regulators (2008), CESR's advice on Canadian and South Korean GAAPs (CESR/08-293), May 2008, available on www.esma.europa.eu.

Committee of European Securities Regulators (2008), CESR's technical advice to the European Commission on Indian GAAP (CESR/08-859), November 2008, available on www.esma.europa.eu.

Decision no. 2006/891/EC of the Commission on the use by third country issuers of securities of information prepared under internationally accepted accounting standards, published in the Official Journal of the EU no. L 343/2006.

Decision no. 2008/961/EC of the Commission on the use by third countries' issuers of securities of certain third country's national accounting standards and International Financial Reporting Standards to prepare their consolidated financial statements, published in the Official Journal of the EU no. L 340/2008, with subsequent amendments by means of the Commission Implementing Decision no. 2012/194/EU published in the Official Journal of the EU no. L 103/2012.

Directive 2003/71/EC of the European Parliament and of the Council of 4 November 2003 on the prospectus to be published when securities are offered to the public or admitted to trading and amending Directive 2001/34/EC, published in the Official Journal of the EU no. L 345/2003 (EU).

Directive 2004/109/EC of the European Parliament and of the Council of 15 December 2004 on the harmonisation of transparency requirements in relation to information about issuers whose securities are admitted to trading on a regulated market and amending Directive 2001/34/EC, published in the Official Journal of the EU no. L 390/2004 (EU).

EFRAG (2013), The EU endorsement status report, Position as at 12 September 2013, available on http://www.efrag.org/WebSites/UploadFolder/1/CMS/Files/ Endorsement\%20status\%20report/EFRAG_Endorsement_Status_Report_12_ September_2013.pdf.

Epstein, B. J., Jermakowics, E. K., Wiley (2007), IFRS 2007: Interpretarea şi aplicarea Standardelor Internaţionale de Contabilitate şi Raportare Financiară, BMT Publishing House, Bucharest.

European Commission (2010), Report to the European Securities Committee and to the European Parliament on convergence between International Financial Reporting Standards (IFRS) and third country national Generally Accepted Accounting Principles (GAAPs), [COM(2010)292 final], Brussels, 4.6.2010, available on http://ec.europa.eu/internal_market/accounting/docs/com-2010292/com-2010-292_en.pdf.

Feleagă, (Malciu), L., Feleagă, N. (2005), Contabilitate financiară: o abordare europeană şi internaţională, Vol. I, Infomega Publishing House, Bucharest.

Gîrbină, M. M., Bunea, Şt. (2007), Sinteze, studii de caz şi teste grilă privind aplicarea IAS (revizuite)-IFRS, Vol. I., CECCAR Publishing House, Bucharest.

Granier, R. (2003), Les normes comptables internationales, Deuxième partie: la mise en oeuvre, Revue Écho-Gestion, $n^{\circ} 3$, déc.

Regulation (EC) no. 1126/2008 of the Commission adopting certain international accounting standards in accordance with Regulation (EC) no. 1606/2002 of the European Parliament and of the Council, published in the Official Journal of the EU no. L 230/2008.

Regulation (EC) no. 1569/2007 of the Commission establishing a mechanism for the determination of equivalence of accounting standards applied by third country issuers of securities pursuant to Directives 2003/71/EC and 2004/109/EC of the 
European Parliament and of the Council, published in the Official Journal of the EU no. L 340/2007, with subsequent amendments by means of the Commission Delegated Regulation (EU) no. 310/2012, published in the Official Journal of the EU no. L 103/2012.

Regulation (EC) no. 1606/2002 of the European Parliament and of the Council of 19 July 2002 on the application of international accounting standards, published in the Official Journal of the EU no. L 243/2002.

Regulation (EC) no. 1725/2003 of the Commission adopting certain international accounting standards in accordance with Regulation (EC) no. 1606/2002 of the European Parliament and of the Council, published in the Official Journal of the EU no. L 261/2003.

Regulation (EC) no. 809/2004 of the Commission implementing Directive 2003/71/EC of the European Parliament and of the Council as regards information contained in prospectuses as well as the format, incorporation by reference and publication of such prospectuses and dissemination of advertisements, published in the Official Journal of the EU no. L 149/2004, with subsequent amendments by means of the Commission Regulation (EC) no. 1787/2006 (JO L 337/2006), the Commission Regulation (EC) no. 1289/2008 (JO L 340/2008) and the Commission Delegated Regulation (EU) no. 311/2012 (JO L 103/2012).

Rotilă, A. (2007), Consideraţii privind modernizarea directivelor contabile în contextul adoptării IAS/IFRS în Uniunea Europeană, in the volume of the Scientific Symposium Contabilitatea şi tehnologiile informaţiei şi comunicării, EduSoft Publishing House, Bacău, 87-94.

Rotilă, A. (2011), Reglementări şi practici contabile specifice, Alma Mater Publishing House, Bacău. 